\title{
Tizne popular: ¿Una estética marginal?
}

\author{
Popular tizne: A marginal aesthetic? \\ Tizne popular: uma estética marginal?
}

\author{
Jaime Ruiz Solórzano \\ Candidato a doctor en estudios sociales \\ Universidad Surcolombiana \\ jairuso@usco.edu.co
}

\section{Resumen}

Este artículo busca acercarce a la obra “Tizne Popular" producto del trabajo de pregrado presentado por Johan Abath Muñoz Adames, quien a partir de un recorrido por los barrios periféricos y marginales de la capital del departamento del Huila describe la disposición de los espacios y los objetos que conforman la cocina.

Palabras claves: cocina popular, fogones.

\begin{abstract}
This article seeks to approach the work "Tizne Popular" product of the undergraduate work presented by Johan Abath Muñoz Adames, who from a tour of the peripheral and marginal neighborhoods of the capital of Huila department describes the layout of the spaces and objects that make up the kitchen.
\end{abstract}

Keywords: popular cookery, stove. 


\section{Resumo}

Este artigo busca abordar o trabalho "Tizne Popular" do trabalho de graduação apresentado por Johan Abath Muñoz Adames, que, em um tour pelos bairros periféricos e marginais da capital do departamento de Huila, descreve o layout dos espaços e objetos que compõem a cozinha.

Palavras-chave: cozinha popular, fogão.

Con el nombre de “Tizne Popular. La estética de la cocina popular en Neiva" Johan Abath Muñoz Adames (2013) (en adelante Muñoz) llevó a cabo una propuesta de investigación-creación; probablemente recurriendo como metodología al caminar como un manera de investigar y crear (Careri, 2009), recorrió los barrios periféricos y marginales de la capital del departamento del Huila.

En estos lugares ganó la confianza requerida para entrar a los lugares de habitación y los espacios familiares, donde se preparan los alimentos. Allí encontró como "síntomas característicos” (Ibíd.) la disposición de los espacios y los objetos que conforman las cocinas populares, los cuales fueron registrados con técnicas fotográficas. Estas son las imágenes que ilustran la presente edición de la Revista Paideia Surcolombiana.

Los fogones se encontraban improvisados con materiales encontrados como ladrillos, piedras, placas de concreto, o partes metálicas de vehículos y maquinarias adaptados; dispuestos a manera de hornillas de la más variada e inesperada conformación.

El elemento visual común a la serie de fotografías es, como bien fue titulado el trabajo, el "tizne" proveniente de los materiales a los cuales recurre la gente cuando no tienen acceso al combustibles de uso común, como el gas, el petóleo o la gasolina para cocinar; lo que encontró Muñoz fue la combustión de maderas naturales o procesadas, cartones y plásticos principalmente, usados para la misma función. Este mismo "tizne" es también el elemento común que invade los recipientes, los pisos y los muros de los espacios improvisados o construidos que albergan las cocinas.

Para quien no se encuentra familiarizado con los dispositivos, materiales y recursos que emplean los sectores marginales, probablemente tales imágenes resulten kitsch, desagradables, antiestéticas, intolerables; sobre todo, cuando nos encontramos familiarizados con un medio altamente estetizado, producto del sistema socioeconómico en el cual nos encontramos (Michaud, 2007). En este, de hecho, muy poco se alude a la ruina y menos a las 
personas que llevan una vida vulnerable y precaria.

No resultan extrañas las reacciones provocadas por el "Tizne popular", en la medida que es inclasificable dentro de alguna tendencia artística moderna o contemporánea (Smith, 2012); no se trata de expresiones artesanales o de las artes populares (García Canclini, 2002); no son prácticas que se puedan relacionar con la "pornomiseria", entendida como el arte selecto o masivo que recurre a lo popular, con la finalidad de conmover para alcanzar la aceptación o el consumo masivo (Faguet, 2008); tampoco se trata de representantes del llamado "outsider art", producido por personas que aunque tienen una práctica creativa constante no suelen ser registradas como artistas (Wojcik, 2016); de ninguna manera se pueden relacionar con las expresiones urbanas, encaminadas a buscar su reconocimiento (Shusterman, 2002).

Es apenas evidente que los creadores y usuarios de las mencionadas cocinas del mencionado "Tizne popular", jamás han tenido en mente que estuviesen realizando un tipo de planteamiento visual con la intencionalidad de generar alguna experiencia artístico/estética, en eventuales públicos. La estética a la que alude Muñoz puede versar sobre las maneras de hacer sensibles que efectúan las poblaciones empobrecidas; tal vez se trate practicas elementales que toman como punto de partida la experiencia ordinaria de la vida cotidiana (Dewey, 2008), y que sin ningún tipo de intencionalidad ponen en común la marginalidad y lo precario.

Es probable que Muñoz haya efectuado una entrada a otra estética, como una especie de aporte a la avalancha de ellas que desde hace unos años vienen emergiendo. Con ello Muñoz estaría corriendo un velo para fijar su mirada y su lente en el "punctum" (Barthes, 1989), en lo inadvertido, lo oculto o invisible para el observador común o con el ojo ilustrado.

Por ello, se trataría de una estética percibida y asumida como una serie de prácticas, soluciones materiales/visuales que son ejercidas ante las necesidades básicas; que nos hablan, como diría Camargo (2017), de "formas diabólicas" totalmente opuestas a las "canonizadas"; es decir de las reconocidas y avalas por el mundo del arte. En esencia, lo que plantea Muñoz es una invitación a expandir y resignificar nuestras percepciones y conceptos sobre lo que aceptamos comúnmente como artístico/estético.

\section{Referencias}

Barthes, Ronald (1989). La cámara lucida. Notas sobre la fotografía. Barcelona: Paidós.

Camargo, Marcos H. (2017). Formas diabólicas ensaios sobre 
cogniçao estética. Londrina: Syntagma.

Careri, Francesco (2009). Walkscapes. El andar como practica estética. Walging as an aesthetic practlce. Barcelona: Gustavo Gili.

Dewey, John (2008). El arte como experiencia. Barcelona: Paidós.

Faguet, Michel (2008). Je est un autre: la estetización de la miseria. En Ministerio de Cultura. Ensayos sobre arte contemporáneo en Colombia 2007-2008. Bogotá: MinculturaUniandes.

García Canclini, Néstor. (2002). Culturas populares en el capitalismo. México: Grijalbo.

Michaud, Yves (2007). El arte en estado gaseoso. Ensayos sobre el triunfo de la estética. México: FCE.

Shusterman, Richard (2002). Estética pragmatista: viviendo la belleza, repensando el arte, Barcelona: Idea Books.

Smith, Terry (2012). ¿Qué es el arte contemporáneo?. Buenos Aires: Siglo XXI.

Wojcik, Daniel (2016). Outsider art. Visionary worlds and trauma. Jackson: University Mississippi. 